\title{
FAKTOR YANG MEMPENGARUHI WISATAWAN MEMBELI PRODUK HIJAU DI BALI BUDA UBUD, GIANYAR
}

\author{
I Made Cahya Narayana ${ }^{1}$, I Made Kusuma Negara ${ }^{2}$, NMS. Wijaya ${ }^{3}$ \\ ${ }^{1}$ Email: cahyanarayana14@gmail.com \\ Program Studi Industri Perjalanan Wisata, Fakultas Pariwisata, Universitas Udayana \\ 2Email: kusuma.negara@unud.ac.id \\ Program Studi Industri Perjalanan Wisata, Fakultas Pariwisata, Universitas Udayana \\ ${ }^{3}$ Email: mdsofiawij@gmail.com \\ Program Studi Industri Perjalanan Wisata, Fakultas Pariwisata, Universitas Udayana
}

\begin{abstract}
Abstrack: Green product is one of the breakthrough innovations from the industry especially the tourism industry to achieve sustainable development. There are several reasons why the green product is an eco-friendly product such as the use of organic ingredients and the production process. Hence, the objective of this research is to indentificate what is the factors affecting tourist' Willingness to pay for the green products at Bali Buda Ubud Gianyar and what kind of factor that dominantly affects tourists' willingness to pay Bali Buda Ubud green product. This research uses quantitative data technique analysis which processed by SPSS 23.0 for windows application. The sample is determined by a purposive sampling technique with 105 tourists who buy the green product of Bali Buda Ubud. The data collection techniques are observation, questionnaire, interview, literature review, and documentation. The data analysis techniques from this research are the validity test, reliability test, and factor analysis. The result of this research was that the factors which affect tourist' willingness to pay green product of Bali Buda Ubud were company profit for environment conservation, green product good for health, the uniqueness of green product packaging, the pride of buying the green product, and knowledge about the green product. The dominant factor which affects tourist' willingness to pay green product of Bali Buda Ubud was company profit for environment conservation which is seen from the biggest eigenvalue 8.373 and variance presentation $39.872 \%$.
\end{abstract}

\begin{abstract}
Abstrak: Produk hijau adalah salah satu bentuk terobosan para pelaku usaha terutama usaha pariwisata untuk menciptakan pembangunan berkelanjutan. Ada beberapa alasan mengapa produk hijau ini adalah produk yang ramah lingkungan seperti bahan organik yang digunakan, proses produksi hingga pengemasan yang menggunakan prosedur ramah lingkungan. Oleh karena itu tujuan dari penelitian ini adalah untuk mengetahui faktor-faktor apa saja yang mempengaruhi kesediaan wisatawan membayar pada produk hijau di Bali Buda Ubud Kabupaten Gianyar. Penelitian ini menggunakan teknik analisis data deskriptif kuantitatif yang diolah menggunakan aplikasi SPSS 23.0 for windows. Sampel ditentukan dengan teknik purposive sampling berjumlah 105 orang wisatawan yang membeli produk hijau Bali Buda Ubud Kabupaten Gianyar. Teknik pengumpulan data yang dilakukan dengan cara observasi, kuesioner, wawancara, studi kepustakaan, dan dokumentasi. Teknik analisis data dari penelitian ini adalah uji validitas, uji realibilitas, dan analisis faktor. Hasil dari penelitian ini diketahui faktor-faktor yang mempengaruhi kesediaan wisatawan membayar pada produk hijau Bali Buda Ubud Kabupaten Gianyar yaitu keuntungan perusahaan untuk pelestarian lingkungan, produk hijau baik untuk kesehatan, keunikan tampilan produk hijau, kebanggaan membeli produk hijau dan pengetahuan tentang produk hijau. Faktor dominan yang memepengaruhi kesediaan wisatawan membayar pada produk hijau di Bali Buda Ubud Kabupaten Gianyar adalah keuntungan perusahaan untuk pelestarian lingkungan dapat dilihat melalui nilai eigenvalue terbesar yakni sebesar 8.373 dan persentase variance sebesar $39.872 \%$.
\end{abstract}

Keywords: bali buda, factor analysis, green product, willlingness to pay. 


\section{PENDAHULUAN}

Produk hijau adalah produk yang diproduksi menggunakan bahan yang bebas dari bahan berbahaya dan menggunakan prosedur yang ramah lingkungan (Gurau dan Ranchhod, 2005). Perkembangan penggunaan produk hijau atau green lifestyle terus meningkat setiap tahunnya. Hal ini berbanding lurus dengan penelitian yang dilakukan Global Web Index Q2 2018 yang menyatakan jumlah penduduk dunia yang memilih produk hijau akan meningkat signifikan dalam 10 tahun kedepan. Keberadaan produk hijau merupakan salah satu inovasi untuk mengatasi beberapa permasalahan lingkungan yang banyak terjadi. Dengan keunggulannya tersebut tidak mengherankan jika harga produk hijau lebih tinggi dibandingkan produk biasa. Menarik lebih lanjut untuk diteliti bagaimana sebenarnya para penikmat produk hijau rela membayar lebih untuk harga sebuah produk hijau. Kesediaan wisatawan membayar dapat diartikan sebagai tedensi atau sebuah perilaku dari konsumen untuk rela membayar lebih untuk jenis kebutuhan yang masuk kedalam intention konsumen tersebut.(Kotchen \& Reiling (2000)). Ada beberapa hal yang menyebabkan perilaku kesediaan wisatawan membayar pada produk hijau yakni awareness of green product, quality, social image. uniqueness, dan costumer' responsiveness to corporate environmental practices.

Industri restoran serta makanan dan minuman merupakan industri yang paling banyak kedua menyumbang devisa pariwisata di Indonesia. Bali Buda merupakan sebuah restoran dan toko aminitas di Bali yang menawarkan produk makanan, minuman, hingga produk ramah lingkungan yang mendukung healthy life style atau gaya hidup sehat dengan makanan organik sebagai produk unggulannya. Ada beberapa hal yang menjadikan Bali Buda sebagai perusahaan hijau yang menghasilkan produk hijau. Dari sisi awareness of green product Bali Buda gencar mempromosikan pentingnya sustainability dalam bisnis mulai dari restorant, outlet hingga sosial media rutin mengkampanyekan pentingnya keberadaan produk hijau. Quality (kualitas) juga menjadi hal penting yang menjadi pertimbangan Bali Buda dalam memproduksi produknya untuk memastikan produknya berkualitas tinggi dan aman bagi kesehatan.
Selain itu produk Bali Buda juga memiliki Uniqueness (Keunikan) tersendiri baik dari segi tampilan hingga cara pengkemasannya. Hingga komitmen untuk ikut berpartisipasi dalam pelestarian lingkungan melalui beberapa LSM seperti Eco Bali dan kampanye Bali Cantik Tanpa Plastik. Alasan ini yang mendorong penulis untuk melakukan penelitian di Bali Buda Bali Buda Ubud dipilih secara spesifik karena kawasan Ubud merupakan sentra pariwisata spiritual dan wellness yang erat kaitannya dengan keberadaan produk hijau, yang nantinya penelitian ini bisa mengidentifikasi tentang karakteristik wisatawan penikmat produk hijau dan faktor apa saja yang mempengaruhi mereka untuk rela membayar lebih pada produk hijau Bali Buda Ubud Kabupaten Gianyar.

\section{METODE}

Pengumpulan data dilakukan di Bali Buda Ubud Kabupaten Gianyar. Adapun alasan dalam memilih lokasi ini adalah keberadaan Bali Buda sebagai perusahaan yang menjual produk hijau dan juga letak Bali Buda Ubud di sentral pariwisata Ubud yang menjadi pusat pariwisata spiritual dan wellness yang erat kaitannya dengan produk hijau. Variabel yang digunakan berdasarkan teori willingness to pay yaitu Awarness of Green Product (Kesadaran akan Produk Hijau), Green Product Quality for health (Kualitas Produk Hijau bagi kesehatan), Social image (Citra Sosial), Uniqueness (Keunikan) dan Costumers Responsiveness to corporate environmental practices. Teknik pengumpulan data dilakukan dengan observasi, kuesioner, wawancara, studi kepustakaan, dan dokumentasi. Teknik pengambilan sampel dilakukan dengan purposive sampling. Pengumpulan data dilakukan dengan penyebaran kuesioner terhadap 105 responden. Teknik analisis data dilakukan dengan uji validitas, uji reliabilitas, dan analisis faktor.

\section{HASIL DAN PEMBAHASAN}

Berikut ini adalah karakteristik wisatawan yang mempunyai perilaku kesediaan membayar pada produk hijau di Bali Buda Ubud Kabupaten Gianyar. Wisatawan mancanegara mendominasi terbanyak berasal dari Belanda diikuti wisatawan nusantara yang didominasi asal Jakarta. Wisatawan yang memiliki kesediaan wisatawan membayar 
pada produk hijau Bali Buda Ubud di dominasi oleh perempuan dengan wisatawan yang berstatus belum menikah. Wisatawan berusia 19-30 tahun (milenial), dengan pekerjaan sebagai freelance, berpendidikan sarjana adalah karakteristik wisatawan yang mempunyai kesediaan membayar pada produk hijau Bali Buda Ubud Kabupaten Gianyar. Dari karakteristik psikografis wisatawan yang mempunyai kesediaan wisatawan membayar pada produk hijau Bali Buda Ubud Kabupaten Gianyar melakukan kunjungan 2-3 kali, dengan pengeluaran Rp.50.000-Rp. 200.000 per-kunjungan. Informasi yang didapatkan terbanyak berasal dari teman atau keluarga dan produk hijau yang paling banyak dibeli adalah produk makanan.

Untuk mengetahui faktor-faktor yang mempengaruhi kesediaan wisatawan membayar pada produk hijau di Bali Buda Ubud Kabupaten Gianyar, mendapatkan hasil analisis data sebagai berikut. Terdapat 5 faktor yang terbentuk diantaranya adalah Keuntungan Perusahaan untuk Pelestarian Llingkungan, Produk Hijau Baik untuk Kesehatan, Keunikan Tampilan Produk hijau, Kebanggaan (Prestige) Membeli Produk Hijau, dan Pengetahuan Tentang Produk Hijau. Berdasarkan hasil analisis maka yang menjadi faktor yang paling dominan yaitu faktor keuntungan perusahaan untuk pelestarian lingkungan. Faktor ini terdiri atas empat variabel yaitu: (1). Saya lebih memilih produk hijau di Bali Buda Ubud Kabupaten Gianyar karena perusahaan ini menyisihkan keuntungan penjualannya untuk pelestarian lingkungan. (2). Saya membayar produk hijau di Bali Buda Ubud Kabupaten Gianyar karena Bali Buda Ubud Kabupaten Gianyar memiliki produk hijau dengan dampak yang positif bagi lingkungan. (3).Saya membayar harga produk hijau di Bali Buda Ubud Kabupaten Gianyar karena saya merasa memiliki tanggung jawab bagi lingkungan. (4). Saya lebih memilih produk hijau di Bali Buda Ubud Kabupaten Gianyar karena perusahaan menggunakan material daur ulang.

Faktor keuntungan perusahaan hijau untuk pelestarian lingkungan mengungguli faktor lain, hal ini menunjukan bahwa wisatawan yang mempunyai kesediaan membayar pada produk hijau di Bali Buda menyadari bahwa pentingan perusahaan atau industri untuk menyisihkan hasil penjualan mereka untuk pelestarian lingkungan. Mereka mengangap tidak masalah untuk membayar lebih pada produk hijau, dengan syarat perusahaan mampu menyisihkan keuntungan mereka untuk kegiatan konservasi dan pelestarian lingkungan.

\section{SIMPULAN DAN SARAN Simpulan}

Analisis data dan pembahasan faktorfaktor yang mempengaruhi kesediaan wisatawan membayar pada produk hijau di Bali Buda Kabupaten Gianyar, maka dapat diambil simpulan sebagai berikut. Terdapat lima faktor yang mempengaruhi kesediaan wisatawan membayar pada produk hijau di Bali Buda Ubud Kabupaten Gianyar. Faktor pertama adalah keuntungan perusahaan untuk pelestarian lingkungan, faktor kedua adalah produk hijau baik untuk kesehatan, faktor ketiga adalah keunikan tampilan produk hijau, faktor keempat adalah kebanggaan (Prestige) membeli produk hijau, dan faktor kelima adalah pengetahuan tentang produk hijau. Berdasarkan hasi analisis faktor. Faktor yang paling dominan mempengaruhi kesediaan wisatawan membayar pada produk hijau di Bali Buda Ubud Kabupaten Gianyar adalah keuntungan perusahaan untuk perusahaan hijau. Faktor ini terdiri atas empat variabel yaitu: (1). Saya lebih memilih produk hijau di Bali Buda Ubud Kabupaten Gianyar karena perusahaan ini menyisihkan keuntungan penjualannya untuk pelestarian lingkungan. (2). Saya membayar produk hijau di Bali Buda Ubud Kabupaten Gianyar karena Bali Buda Ubud Kabupaten Gianyar memiliki produk hijau dengan dampak yang positif bagi lingkungan. (3).Saya membayar harga produk hijau di Bali Buda Ubud Kabupaten Gianyar karena saya merasa memiliki tanggung jawab bagi lingkungan. (4). Saya lebih memilih produk hijau di Bali Buda Ubud Kabupaten Gianyar karena perusahaan menggunakan material daur ulang.

\section{Saran}

Dari hasil wawancara banyak wisatawan yang memberikan saran untuk lebih menekankan promosi produk hijau di Bali Buda Ubud Kabupaten Gianyar. Belum ada penjelasan produk-produk hijau yang ditawarkan di outlet maupun sosial media. Kedepannya agar memudahkan wisatawan untuk mengenal produk hijau, pengenalan produk hijau mutlak diperlukan. 
Dalam hal sarana dan prasarana masih perlu ditingkatkanterutama dalam hal ketersediaan lahan parkir. Disamping hal tersebut beberapa produk Bali Buda Ubud Kabupaten Gianyar masih terbungkus oleh bahan yang tidak ramah lingkungan seperti plastik.

Adanya perusahaan yang berorientasi pada keberlanjutan lingkungan harus terus digenjot lagi keberadaannya oleh pemerintah terutama Pemerintah Provinsi Bali. Hal ini bisa diterapkan melalui peraturan dan kebijakan khusus untuk mendorong lagi perusahaan hijau di Bali.

Penelitian ini belumlah sempurna, kedepan civitas akademika Fakultas Pariwisata Universitas Udayana bisa mengembangkan lagi penelitian ini tidak hanya dilakukan di Bali Buda Ubud Kabupaten Gianyar tetapi juga perusahaan lain dengan visi dan misi yang sama terutama dalam hal keberlanjutan lingkungan.

Kedepannya para peneliti yang ingin melanjutkan penelitian produk hijau bisa memperluar cakupan penelitiannya dengan menambahkan masyarakat lokal dan perusahaan hijau sebagai objek penelitian. 


\section{Kepustakaan}

Anselmsson, J., Bondesson, N., and Johansson, U. (2014) "Brand image and customers'Kesediaan Wisatawan Membayar a price premium for food brands". Journal of Product \& Brand Management. 23, 90-102.

A, Yoeti, Oka. (1996). Pengantar Ilmu Pariwisata. Bandung: Angkasa.

Biswas, Aindrila. (2016). A Study of Consumers' Kesediaan Wisatawan Membayar for Green Products. Journal of Advanced Management Science Vol. 4, No. 3, May 2016 doi: 10.12720.

Gurau, C. and Ranchhod, A. (2005). International green marketing: a comparative study of British and Romanian firms. International Marketing Review, Vol. 22 No. 5, pp. 547-561.

Grujic, S., Grujic, R., Petrovic, D., and Gajic, J. (2013) Knowledge of food quality and additives and its impact on food preference. Academy Science, Politics, Technology.12 (2), 215-222.

Hair, et al. 2006. Multivariate Data Analysis 6th Ed. New Jersey : Pearson Education.

Kotchen, M. J. Reiling, S.D. 2000. Environmental attitudes, motivations, and contingentvaluation of nonuse values: a case study involving endangered species. Ecological Economics 32 (2000) 93-107.

Laroche, M., Bergeron, J., Barbaro-Forleo, G., 2001. Targeting consumers who are willing to pay more for environmentally friendly products. J. Consum. Mark. 18 (6), 503-520.

Malik, M.E., Ghafor, M.M., Iqbal, H.K. (2013) "Importance of brand awareness and brand loyalty in assessing purchase intentionof consumer". International Journal of Business and Social Science. 4 (5), 167-171.
Riorini.S.V. Berliyanti. D.O. (2015). Anteseden Dari Wilingness To Pay A Price Premium Dan Konsekuensinya Terhadap Purchase Intention Of Green Product. Jurnal Manajemen/Volume XIX, No. 03, Oktober 2015: 304-320.

Sugiyono.(2001). Metode Penelitian Kuantitatif, Kualitatif \& RND. Bandung:Alfabeta.

Vlosky, R.P., Lucie K. O., and Renee J.F. (1999) A conceptual model of US consumer willingness-to-pay for environmentally certified wood products. Journal of Consumer Marketing. 16 (2), 122-140.

Yaseen, N., Tahira, M., Gulzar, A., and Anwar, A. (2011) Impact of brand awarenes,perceived quality and customer loyalty on brand profitability and purchase intention:a resellers' view. Interdisiplinary Journal of Contemporary Research in Business. 3(8), 833-839. 